IRSTI 13.11 .44

\author{
Bissenbayeva A.P. ${ }^{1}$, Abdurakyn N. ${ }^{2}$, Luo X.M. ${ }^{3}$, \\ ${ }^{1}$ doctoral student, ${ }^{2}$ doctor of philology sciences, $\mathrm{PhD}$, \\ al-Farabi Kazakh national university, Kazakhstan, Almaty, \\ ${ }^{3}$ doctor of philology sciences, professor, \\ e-mail:w-5@mail.ru, abdurakyn.nurhalyk@mail.ru,xuanmin14@163.com
}

\title{
FEATURES OF THE CHINESE NETWORK LITERATURE
}

The article discusses the history of the development of network literature in China, as well as its place in modern society. Modern literature has lost its homogeneous nature, divided into the one that exists in the traditional form of paper literature, and the one that develops in the network format. Some researchers of online literature associate the story of its origin with the emergence of universal electronic libraries and the digitization of world literature. The proposed article identifies the positive and negative aspects of the development of network works, the main problems of popularizing this area in the literature. Based on the two most popular Chinese sites, an analysis was conducted to identify the most widely read works in the network and the most popular genres in modern China, such as fantasy, fantasy and romance. Today, «online literature» can already be considered as a definite historical stage: it did not generate any significant artistic works or new genre models, but it gave impetus to the development of modern literature. In relation to it, it serves as the environment in which the phenomena of the modern literary process are formed.

Key words: China, web literature, online literature in China, modern Chinese writers, web literature genres, problems of web literature development, Chinese culture.

\author{
Бисенбаева А.П. ${ }^{1}$, Абдұрақын Н. ${ }^{2}$, ^уо С.М. ${ }^{3}$, \\ әл-Фараби атындағы Қазақ, ұлттық, университетінің \\ 1PhD докторанты, ²оқытушысы, PhD, Қазақстан, Алматы қ. \\ ${ }^{3}$ Цинхуа университетінің профессоры, PhD, Қытай, Пекин қ., \\ e-mail: w-5@mail.ru, abdurakyn.nurhalyk@mail.ru, xuanmin14@163.com
}

\section{Қытай ғаламтор әдебиетінің ерекшелігі}

Мақалада Қытайдағы ғаламтор әдебиетінің даму тарихы мен оның қазіргі қоғамдағы орны қарастырылады. Қазіргі әдебиет өзінің біртектес табиғатын жоғалтып, қағаз түріндегі және ғаламтор әдебиет форматы болып екіге бөлінді. Ғаламтор әдебиетінің зерттеушілері оның даму тарихын әмбебап электрондық кітапханалар мен әлем әдебиеті шығармаларының электронды формаларының пайла болуымен байланыстырады. Берілген мақалада ғаламтор шығармаларының жетістіктері мен кемшіл тұстары, сонымен қатар бұл әдебиет бағытының негізгі мәселелері ашып көрсетілді. Екі әйгілі қытай сайтының негізінде қазіргі Қытайдағы ең көп оқылатын ғаламтордағы шығармаларды анықтап, фантастика, фэнтези және романтика жанрларына жастардың арасында сұранысқа ие болу себебін айқындадық. Бүгінде «ғаламтор әдебиеті» бөлек бір тарихи кезең болып қарастырылады: ол ешқандайда маңызды көркем шығармалар тудырмады, жаңа бір жанр енгізбеді, дегенмен ол қазіргі әдебиеттің дамуына түрткі болды. Қазіргі таңда ғаламтор әдебиеті заманауи әдебиет үлерісінің қалыптасуындағы маңызды фактор болып табылады.

Түйін сөздер: Қытай, ғаламтор әдебиеті, Қытайдағы желілік әдебиет, Қытай жазушылары, қытай мәдениеті, даму проблемасы. 


\author{
Бисенбаева А.П. ${ }^{1}$, Абдурақын Н. ${ }^{2}$, Ауо С.М. ${ }^{3}$ \\ ${ }^{1} \mathrm{PhD}$ Аокторант, ${ }^{2} \mathrm{PhD}$, \\ Казахский национальный университет имени аль-Фараби, Казахстан, г. Алматы, \\ ${ }^{3}$ профессор Университета Цинхуа, PhD, Китай, г. Пекин, \\ e-mail: w-5@mail.ru, abdurakyn.nurhalyk@mail.ru, xuanmin14@163.com
}

Особенности китайской интернет-литературы

\begin{abstract}
В статье рассматривается история интернет-литературы, и ее роль в современном обществе Китая. В настоящее время литература делится на два вила - традиционная печатная митература, и китература в сетевом формате. Исследователи сетевой литературы связывают её историю появления с возникновением электронными библиотеками и электронными форматами печатных мировых произведений. В Аанной статье представлены достоинства и недостатки развития интернет-произведений, основные проблемы данного направления, а также их основные преимущества в литературе. Проведен анализ интернет-произведений двух самых популярных сайтов Китая, а также выявлены причины популярности таких жанров как фантастика, романтика и фэнтези среди молодежи. На сегодняшний день «интернет-литература» является отдельной эпохой в истории китературы: хотя в сетевой митературе нет великих произведений или новых жанров, однако она стала толчком в развитии современной митературы. Сетевая митература яв^яется важным фактором в процессе становления современной китайской литературы.

Кмючевые слова: Китай, веб-литература, сетевая литература в Китае, современные писатели Китая, жанры веб-литературы, проблемы развития веб-литературы, китайская культура.
\end{abstract}

\section{Introduction}

At the end of the 20th century, computer technologies interrelated with such aesthetic, moral and philosophical value as fiction. The beginning of close interaction of traditional literary activity and information technologies led to the birth of a phenomenon called «network literature» or «set literature» (a neologism that has arisen in recent decades). Under the network literature understand electronic literary text, placed directly in the international network. This phenomenon has received wide support among novice writers who do not have the opportunity, sufficient funds, and, as a rule, fame (the nonebrand) for publishing their works in literary journals or for publishing their own literary texts in print. Online literature immediately became popular due to the well-known advantages of an electronic document.The current definition of online literature is quite controversial. However, the Internet literature is a new literary work, a literary text and a network art containing a part of literary composition, which is based on the Internet as a platform for display and a medium of communication, with the help of hypertext links and multimedia interpretation (Basova, 2015:23). With the popularity of Dian ZiCa's «First contact» on the Internet, the word «network literature» is gradually known. The genre of «network literature» is roughly divided into poetry, prose, novels, etc. Among them, there are many novels, the main forms include spiritual aliens, urban romance, game competition, etc.

Today it has become one of the dominant trends in modern literature. The authors of most online literature write for the purpose of writing hobbies or writing online to express their opinions and feelings. Next, we will do a brief summary to the modern Internet literature.

\section{Experiment}

I. The characteristics of online literature. To meet the demands of netizens for diverse reading conditions and following development of science and technology, reading tools such as books, notebooks and newspapers have gradually been replaced by tools such as computer and mobile phones. Therefore, in the new era of science and technology, online literature has emerged, such as the spiritual class, the crossing class better meets the entertainment needs of the readers. The birth of network literature under the conditions of freedom and broad network makes it free and easy, and it is conducive to breaking the boring atmosphere of the traditional literary world (Seteratura, 2005:269). At the same time, online literature has a super-communication function, and its development speed is rapid. It is also the liberation of the author's copyright rights, and the realization of the "everyone is an artist». Subversion and deconstruction, network literature emerged in the post-modern period, which must have modern characteristics, embody the spirit of tolerance and freedom. Online literature embodies postmodernism, deconstructive thinking, and most online literary works. In content and writing skills, we strive to be different, such as through novels, scifi fantasy novels, detective novels, and the works have some madness against the normal. The writers 
are trying to open the external objective world, but the entertainment needs that attract readers to click (Xiao Zhong, 2000:15).

II. Problems in the development of network literature. The former network literature mainly focuses on novels mainly because of the unique operation mode of online literature. This mode of operation makes many works very commodity, and «literary» is relatively light, and this mode of operation is difficult to use in poetry, prose and other small genres. (Kuchina, 2015:119) Therefore, some web writers take commercial profits as their writing purpose. At firtst, the threshold of online literature is low. Many authors of online literature are writing for the first time, and some are part-time. In addition, the network itself has a strong randomness, which leads to the improvement of the ideological and technical skills of some works. The authors of online literature are young, mostly lacking the accumulation of life and artistic accumulation. This will inevitably weaken the literary ideology. The theme of cyber literature is basically about the love of the ancestor of online literature, the storage of a pro touch or the later love story, etc. The topics are relatively simple. It can be seen that the network writers are engaged in the gesture of personal care, but lack the attitude of humanistic care. They do not show that the world is their own responsibility. Second, network literature is considered more entertaining than paper literature. It does not need Paper literature is as refined and elegant, skillful, mature, and immature, and it is an overly mature advantage against paper literature. Third, literature should reflect social life through the storyline and character image. The current online literature works rarely create a better image of network tasks. Most of the characters are relatively simplistic, and the flatness is visible. The artistic achievements of online literature need to be improved. Forth, due to the strong freedom of creation of online literature, it is difficult to supervise. Li Bing, the party secretary of the Chinese Writers Association, said in an interview that he wants to be «highly valued, enthusiastically supported, actively guided, and strengthened management. This is our basic idea» (Xinhua: http://politics.people. com )

III. Solutions and development trends. The emergence of online literature makes history development exposed, and it keeps as a new thing. Its growth will not be smooth, and a process of development needs to be gradually matured. Most of the writers of online literature are young people who was born after 80 or even after 90 years. Their age is very small, so training of these youth teams should arouse everyone's attention. Well-known writers should open up a network literature section and actively become a navigator of the development of online literature. At the same time, young people should be encouraged. The literary creators of the network actively participated in and learned from the older generations. In recent years, the National Writers Association established the «Network Literature Point Garden Work Joint Conference System» according to the actual situation. In 2008, under the guidance of the Chinese Writers Association, «Network Literature Ten» was held. (Baidu: http://www.16an.com/ novel) The annual inventory activity has been well received by all walks of life. In the selection process of the competition, including the people's literature and other heavyweight units, the family has joined the family to seek guidance and promote the healthy development of online literature. Finally, 21 works are highly respected: its begun to actively guide online literature, through regular or insufficient period of class. It seems that activities actively guide the creation of online literature. To improve the development level of online literature, we must first improve the ideological value of online literature. It is said that online literature still relies on clicks to obtain income, and the content of many works is entertaining and grotesque. It is easier to grasp the hearts of young readers.(Hickey, 2015:14) It makes many works, there is hype, and the content is artificial. The authors of Genduo do not care about the structure of the works, the image of the characters. Increase the rational color of online literary criticism, now most of the online literary criticisms are also random and even entertaining. Online literary criticism should also pay attention to the authors of online literature, and cultivate the humanistic spirit in the works. Online literary criticism should be just right, let the readers and authors agree, but also Objective and true, and philosophical, so as to correctly guide readers' needs in mind, we must also strive to guide the purpose of creation. It is possible for the author to continuously learn from criticism and form a sexual cycle of readers, authors and literary critics to realize the charm of online literature. Developing the network has become a must in people's lives. Part of the network creation is also the trend of the times. The Chinese network writer Xiao Huang noted, that network creation has brought great impact to traditional paper literature and people's ideas. (Zhu Lyuan, 2005:125) As a new thing, we must actively guide and develop hard. The majority of online literature writers will also keep up with the times: 
development, continuous innovation, progress and ultimately success.

\section{Results of the experiment and discussion}

The artistic text placement services provided by websites are practically free of charge, which makes online publications attractive for this category of writers. Online literature is a work written for further publication in the network. Most often web works are multi-serial and periodically updated. Despite the rapid development and growth of popularity, this area is still little studied. As for the Chinese web literature, in Kazakhstan it still remains unexplored. However, watching the rapid rise of China on the world stage, it can be assumed that interest in the Chinese network culture will also increase.

Chinese online literature originated in the early 1990s. 20th century. As we know same year for China was registered top-level domain .cn. In 1995, China Telecom began providing Internet services via telephone lines, DDN and $\mathrm{X}$ network. The company is also starting to build the Chinanet state network (Sina Technology: http://www.16.qr.com/ news $/ 1597 /$ novelist ). It is these first steps that can be considered the beginning of the appearance of network literature in China.

In 1991 Wang Xiaofei founded the Chinese literary site - «Chinese poetry network» . In April 1991 Shao Jun published his first online novel «Struggle and equalit», becoming the first Chinese Internet writer. In March 1995, the first poetry collection «Olive tree», founded by Shi Yang. At the end of 1995 was based the first online journal of women's literature called «Trick», poems of several female authors were published there. Internet cafes are emerging in mainland China. In 1999, the largest literary site «Under the banyan tree» was founded, after which Web literature began to flourish. In the 21 st century, thanks to new technologies, literary sites continue to evolve, more and more people prefer online literature.

The Central Committee of the CPC on the development and prosperity of literature and art also expressed the view that it is necessary to actively develop online literature (Renmin ribao: http:// culture.people.com.cn/). In China, seminars are held on the theme «Prospects for the development of network literature.» Such issues as «Issues and Prospects», «Net literature and scientific and technical progress», «Net literature as an important element in modern times» and others are discussed.
Professor Zhou, director of the Shandong Provincial Pedagogical University Research Center, notes that thanks to the convenience and popularity of the Internet, thanks to the support and assistance from the state, online literature is increasingly evolving (Renmin ribao: http://culture.people.com. cn/zhongwen ).

At present, Chinese web literature is also becoming popular outside of China. For example, 《明朝那些事儿》 and 《鬼吹灯》 became popular in Japan. 《仙侠奇缘之花花千骨》 is sold in Thailand. 《步步惊心》 became a bestseller in Korea. For all the time of its development, online literature has been criticized more than once. The main reason for this was the low quality of published works. Web literature has more freedom of thought, which is undoubtedly a plus for authors and readers. However, on the other hand, this is the dominance of the Chinese Internet with low-quality novels of dubious content. It is this problem that the PRC government has been concerned about in recent years.

It is also disturbing that in the modern world, people are increasingly becoming dependent on the network. According to the China Information Center (CNNIC), in 2013. The number of users of web literature has reached 260 million people. (Online literature contributes: http://www.bbc.com). Most of them were young people. According to statistics, the number of users dependent on the web literature exceeds $50 \%$, of which $2.3 \%$ of users need to view the online literature daily.

It should be noted that the web authors themselves suffer from such a high speed of work. Many writers can work all night and this seriously affects their health. There are several cases when writers died from exhaustion. Since May 2013, some publishers have begun paying medical insurance to writers with whom they have contracted (Yijun: http:// www.sixthtone.com/news/1597 ). Despite this, web literature has some positive aspects. Outstanding literary works can be distributed throughout the network in a very short time. A talented web writer can become popular overnight. If the network writer is popular, some publishers are willing to publish it with certain conditions, for example, add a few chapters that are not online, etc.

Quite a few writers who were recognized and published in book format came out of online literature. For example, Shi Yue, who published a historical novel «Ming dynasty affairs» on his blog. The book has become very popular among online readers, and later among buyers. As a result, Shi 
Yue became one of the richest writers in China, in 2011. his income was almost 1 billion dollars. (Zhang Ning, 2009:16).

The first novel by the popular blogger Han Han " Triple Door « was published by many millions of copies, and he became one of the most famous characters in modern China. In 2010, he entered the list of the 50 most influential figures of the world according to the magazine New Statesmen. (Baijiahao: https://baijiahao.baidu.cn ) The wellknown writer Cai Jun, who received the title of "Chinese Stephen King», also emerged from online literature. His books were published, two of them «Virus» and «Spell»- were translated into Russian. In addition, preparing for the film adaptation of his book «The Spell» and «Country House».

\section{Conclusion}

Appearing 20 years ago, Chinese online literature immediately began to grow rapidly. In modern society, it is very popular, mainly among the younger generation. It is impossible to say unequivocally about the impact of web literature on people, because it has its positive and negative sides. The positive points include the rapprochement of the author and readers, the ability of young talents to express themselves. In addition, the network of Chinese writers are beginning to use the European genres of literature, which had not previously been common in China. From this it follows that Chinese literature is becoming increasingly diverse and diversified.

\section{Литература}

Басова М.В. Сетевая литература: проблема эстетической концептуализации, вопросы теории и практики. - Москва, 2015. $-23-27 \mathrm{c}$

Сетература. Современная русская литература (1990-е гг. - начало XXI века). - Москва, 2005. - 269-288 с.

Сяо Джунг. Интернет язык: популярные диалекты современности http://www.chinanews.com/zhonghuawenzhai/2000-12-01

Сина Технология: Рождение онлайн литературы http://www.16.qr.com/news/1597/novelist

Кучина С.А. Электронная литература: жанровые, семантические и структурные особенности. - Москва, 2015. - 119$123 \mathrm{c}$.

Агентство Синхуа: Особенности китайской литературы. http: // politics .people .com .cn /GB / 1026/13867507.

Байду// Китайская интернет литература: http://www.16an.com/novel/538/5314.htm

Дэвид Хиккей. Интернет литература Китая: Сохранение литературного контента BornDigital и борьба с веб-пиратством. - Университет Флорида, 2015. - 14 с.

Джу Лиюань. Теория современной западной литературы. - Университет Шанхая, 2005. - 451 с.

История появления интернета в Китае :http://tech.sina.com.cn/i/2005-07-19/1129666996.shtml?from=wap

Китайский народный журнал. Теория современной литературы. http://culture.people.com.cn/n/2015/1026/c 101327737734.html

Китайская онлайн-литература способствует индустриализации 2015 года: http://www.bbc.com/zhongwen/trad/china/2015/01/150108 ana web literature china

Инь Ицзюнь. Писатель позади хит китайского телешоу, обвиняемого в плагиате 200 работ: http://www.sixthtone.com/ news/1597/novelist-behind-hit-chinese-tv-show-accused-copying-200-works

Чжан Нин. Золото и мусор: два полюса критики современной китайской литературы - Издание Янчен, 2009. - 16 с.

Бай Цзя хао. Мир китайской поэзии https://baijiahao.baidu.com/s?id=159507307885790756

\section{References}

Basova M.V. (2015) Setevaya literatura: problema esteticheskoy kontseptualizatsii, voprosy teorii i praktiki [Network literature: the problem of aesthetic conceptualization]. Moskva, 23-27 p. (in Russian)

Baidu.(2016) Kitaiskaya internet literature [Chinese Internet literature] 14.06.2016 http://www.16an.com/novel/538/5314.htm (in Chinese)

Baijiahao(2015) Mir kitaiskoi poezii [World of Chinese poetry] 26.10 .2015 https://baijiahao.baidu.com/s?id=15950730788579 $07560 \& w f r=$ spider $\&$ for $=$ pc (in Chinese)

David Hickey(2015) Internet literatura Kitaya: Sokhraneniye literaturnogo kontenta BornDigital i bor'ba s veb-piratstvom [Chinese Internet Literature: Preserving BornDigital Literary Content and Fighting Web Piracy]. Universitet Florida, $14 \mathrm{p} \mathrm{(in} \mathrm{English)}$

Hit Chinese TV Show Accused of Plagiarizing 200 Work] 20.03.2017. http://www.sixthtone.com/news/1597/novelist-behindhit-chinese-tv-show-accused-copying-200-works (in Chinese)

BBC(2015) Kitayskaya onlayn-literatura sposobstvuyet industrializatsii 2015 goda [Chinese online literature integrate industry of 2015 year] http://www.bbc.com/zhongwen/trad/china/2015/01/150108_ana_web_literature_china (in English)

Kuchina S.A. (2015) Elektronnaya literatura: zhanrovyye, semanticheskiye i strukturnyye osobennosti [Electronic literature: genre, semantic and structural feature]. Moskva, 119-123p. (in Russian) 
Renmin ribao (2015) Teorya sovremennoi literatury [Theory of modern literature] 25.10.2015 .http://culture.people.com.cn/ n/2015/1026/c 1013-27737734.html (In English)

Seteratura (2005) Sovremennaya russkaya literatura (1990-ye gg. - nachalo XXI veka) [Modern Russian literature] (1990s - the beginning of the XXI century). Moskva, 269-288 p. (in Russian)

Sina Technology (2011). Rojdeniye kitaiskoi literatury [Born of Chinese literature] http://www.16.qr.com/news/1597/novelist

The history of the emergence of the Internet in China // 新浪 科技, 2005, July 19. [Electronic resource]. Shanghaiskii Universitet, 451 p. (in Chinese)

Xiao Zhong(2005). Internet-yazyk: populyarnyye dialekty sovremennosti [Internet language: Popular dialects of modernity] 01.12.2005. http://www.chinanews.com/zhonghuawenzhai/2005-12-01/new/\% 2827\% 29\% 201. Html (in English)

Xinhua News Agency. (2012) Osobennosti kitaiskoi literatury [Features of Chinese literature]. 25.07.2012. http: // politics .people .com .cn /GB / 1026/13867507. Html (in Chinese)

Yin Yijun(2017). Pisatel' pozadi khit kitayskogo teleshou, obvinyayemogo v plagiate 200 rabot [Novelist Behind Zhang Ning(2009). Zoloto i musor: dva polyusa kritiki sovremennoy kitayskoy literatury [Gold and trash: two poles of criticism of modern Chinese literature] // Izdaniye Yanchen, $16 \mathrm{p}$ (in Chinese)

Zhu, Liyuan(2005). Teorya sovremennoi vostochnoi literatury [The Theory of Modern Western Literature]. - Publishing in Shanghai. East.-China. Ped.University, 2005. (in Chinese) 